\title{
Kesesuaian dan daya dukung lingkungan untuk pengembangan ekowisata di kawasan hutan Gunung Mareje Utara Kabupaten Lombok Tengah
}

\author{
Nawari $^{1^{*}}$, Isjoni $^{2}$, Zulkarnaini $^{3}$ \\ ${ }^{1,3}$ Program Studi Ilmu Lingkungan Program Pascasarjana Universitas Riau Pekanbaru \\ ${ }^{2}$ Program Studi Administrasi Pendidikan Program Pascasarjana Universitas Riau Pekanbaru \\ *Koresponden E-mail: n4wari@gmail.com
}

(Diterima 14 Juni 2020 | Disetujui 02 januari 2021 |Diterbitkan 30 Januari 2021)

\begin{abstract}
North Mareje Mountain Forest Area (NMMFA) is one of important areas for ecotourism development in Lombok Island. Currently integrated ecotourism management plan (IEMP) is not available for this area, it has caused land degradation and natural disasters. To support sustainable IEMP establishment, this study was conducted with objectives to analyze land suitability and assessing the environmental carrying capacity of ecotourism development. The study conducted in NMMFA, Serage Village, Central Lombok, NTB during January - March 2020. The data used in this study include attractiveness, landscape naturalness, bio-geophysical limiting factors, accessibility, optimal space requirements and length time of tourist activities. Secondary data compiled from various sources and primary data collected by field observations and interviews. Land suitability analysis used weighted linear combination (WLC), environment carrying capacity analyzed by Douglas Method (Zacarias et al., 2011) and the evaluation conducted by ttest. Based on the analysis, explained that land suitable area for ecotourism in NMMFA is $1.235,2 \mathrm{Ha}$ (75,8\% of total area). Effective carrying capacity (ECC) is 32.729 visitors/day. The important indicators contributed to land suitability include soil conservation, tree diversity, visibility and natural attractiveness. T-test analysis shows that the actual landuse for ecotourism smaller than potential area, the average number of tourist visits in the area also smaller than the ECC. It can be concluded if the current land utilization have been meet with land suitability and environmental carrying capacity.
\end{abstract}

\section{Keywords: capacity, carrying, ecotourism, suitability, sustainable}

Kawasan Hutan Gunung Mareje Utara (KHGMU) memiliki peranan penting dalam menjaga keseimbangan proses ekologis, khsususnya sebagai pengatur siklus air, penyerap dan penyimpan karbon serta memiliki keindahan alam yang dapat dijadikan sebagai destinasi wisata alam. Namun demikian, areal KHGMU telah mengalami kerusakan akibat perambahan hutan dan illegal logging. Pada tahun 2016, tercatat perambahan hutan di kawasan ini mencapai 18,79 Ha. Kerusakan hutan tersebut telah memberikan dampak negatif yang ditimbulkan, yaitu terjadinya bencana banjir dan tanah longsor. Selama kurun waktu dari tahun 2011 sampai dengan 2015 tercatat 16 kejadian bencana banjir dan 8 kejadian tanah longsor di Kabupaten Lombok Tengah (BPS Lombok Tengah, 2017). Penurunan luas lahan bervegetasi sebesar 14,59\% selama kurun waktu 20042014 di daerah aliran sungai (DAS) Utama Dodokan Kabupaten Lombok Tengah dan Lombok Barat, telah menyebab penurunan koefisien aliran tahunan (KAT) secara signifikan yang berpotensi meningkatkan potensi kekeringan (Ilmi, 2019)

Upaya untuk memulihkan kawasan hutan yang telah rusak dilakukan oleh pemangku kebijakan bekerja sama dengan masyarakat yaitu menetapkan kawasan hutan Gunung Mareje menjadi bagian utuh dari kesatuan pengelolaan hutan lindung (KPHL) Tastura dengan salah satu tujuannya adalah membangun core business jasa lingkungan yang meliputi pemanfaatan air, karbon dan ekowisata (Dishutbun Lombok Tengah, 2017). Secara umum pengembangan ekowisata di KHGMU masih belum berjalan optimal karena tidak didukung oleh perencanaan pengembangan ekowisata yang berkelanjutan yaitu mempertemukan antara potensi kawasan dengan minat wisatawan. Hal ini menyebabkan arah pengembangan ekowisata di kawasan ini relatif lambat.

Pemanfaatan hutan sebagai obyek daya tarik wisata merupakan salah satu bentuk pemanfaatan ramah lingkungan selama prinsip - prinsip pariwisata keberlanjutan terimplementasi dengan baik. Salah satu bentuk pariwisata berkelanjutan adalah ekowisata (Wickramasinghe, 2013). Prinsip pengembangan ekowisata menurut Peraturan Menteri Dalam Negeri No.33 Tahun 2009 adalah menyeimbangkan tiga pilar yaitu mencapai kelestarian fungsi ekonomi, sosial dan ekologi.

Untuk mencapai tujuan pengembangan ekowisata diperlukan suatu perencanaan ekowisata berwawasan lingkungan yang memperhatikan permintaan pasar ekowisata, daya dukung lingkungan dan perancangan tapak dengan mempertimbangkan kenyamanan wisatawan tapi tidak menimbulkan dampak negatif terhadap lingkungan (Mirsanjari, 2012). Analisis kesesuaian lahan dan daya dukung lingkungan untuk pengembangan ekowisata adalah satu metode untuk menentukan kesesuaian daya tarik kawasan dengan pengembangan jenis ekowisata tertentu. Analisis ini disusun berdasarkan beberapa kriteria yang terdiri dari keindahan landskap beserta faktor pembatasnya yang meliputi kepekaan tanah, 
iklim, keanekaragaman jenis dan aksesibilitas. Meskipun daya tarik menjadi faktor utama, namun pengembangan ekowisata juga harus mempertimbangkan beberapa faktor pembatas secara seimbang (Bunruamkaew and Murayama, 2011) dan (Bali et al., 2015). Pada setiap kelas lahan yang sesuai, pengelola harus mempertimbangkan jumlah wisatawan yang diperkenankan datang ke lokasi agar tidak melebihi daya dukung lingkungan dengan memperhatikan lama aktivitas dan rotasi wisatawan, luas efektif kawasan, faktor pembatas fisik dan aspek manajemen. Analisis ini berguna sebagai informasi yang esensial dalam penyusunan perencanaan ekowisata terpadu yang berkelanjutan (Kastarlak and Barber, 2014)

Penelitian ini bertujuan untuk mengkaji aspek aspek pengembangan ekowisata berkelanjutan di KHGMU yang mampu menyeimbangkan kelestarian fungsi ekologi, ekonomi dan sosial secara seimbang. Untuk mencapai maksud penelitian tersebut, tujuan penelitian ini ditetapkan secara lebih spesifik adalah : (1) Untuk menganalisis potensi KHGMU yang sesuai untuk pengembangan ekowisata berkelanjutan; dan (2) menganalisis daya dukung lingkungan di KHGMU yang memiliki kesesuainan untuk pengembangan ekowisata. Hasil penelitian ini diharapkan mampu menjadi salah satu input dalam menetapkan kebijakan pengelolaan ekowisata khususnya dalam rangka penyusunan rencana pengelolaan ekowisata terpadu. Penelitian ini juga diharapkan menjadi referensi dalam pengembangan inovasi pembangunan berkelanjutan di masa yang akan datang.

\section{BAHAN DAN METODE}

Penelitian dilaksanakan selama 3 (tiga) bulan, dimulai pada bulan Januari sampai dengan Maret 2020 di Kawasan Hutan Gunung Mareje Utara (KHGMU) yang terletak di Desa Serage, Kecamatan Praya Barat Daya, Kabupaten Lombok Tengah, Provinsi Nusa Tenggara Barat. KHGMU merupakan bagian dari kesatuan pemangkuan hutan lindung (KPHL) Model Tastura secara geografis terletak antara $116^{\circ} 05^{\prime}$ - $116^{\circ} 24^{\prime}$ BT dan dan $8^{\circ} 24^{\prime}$ - $8^{\circ} 57^{\prime}$ LS. Luas KHGMU yang terletak di Desa Serage Kecamatan Praya Barat Daya, Kabupaten Lombok Tengah adalah seluas 1.629,3 Ha. Obyek daerah tujuan wisata alam (ODTWA) yang telah dikunjungi wisatawan terdiri atas 4 lokasi OTDWA, yaitu: (1) Embung Mapasan; (2) Bukit Pupuh; (3) Air Terjun Penangis Simbur; dan (4) Makam Dewa Tongol (Gambar 1).

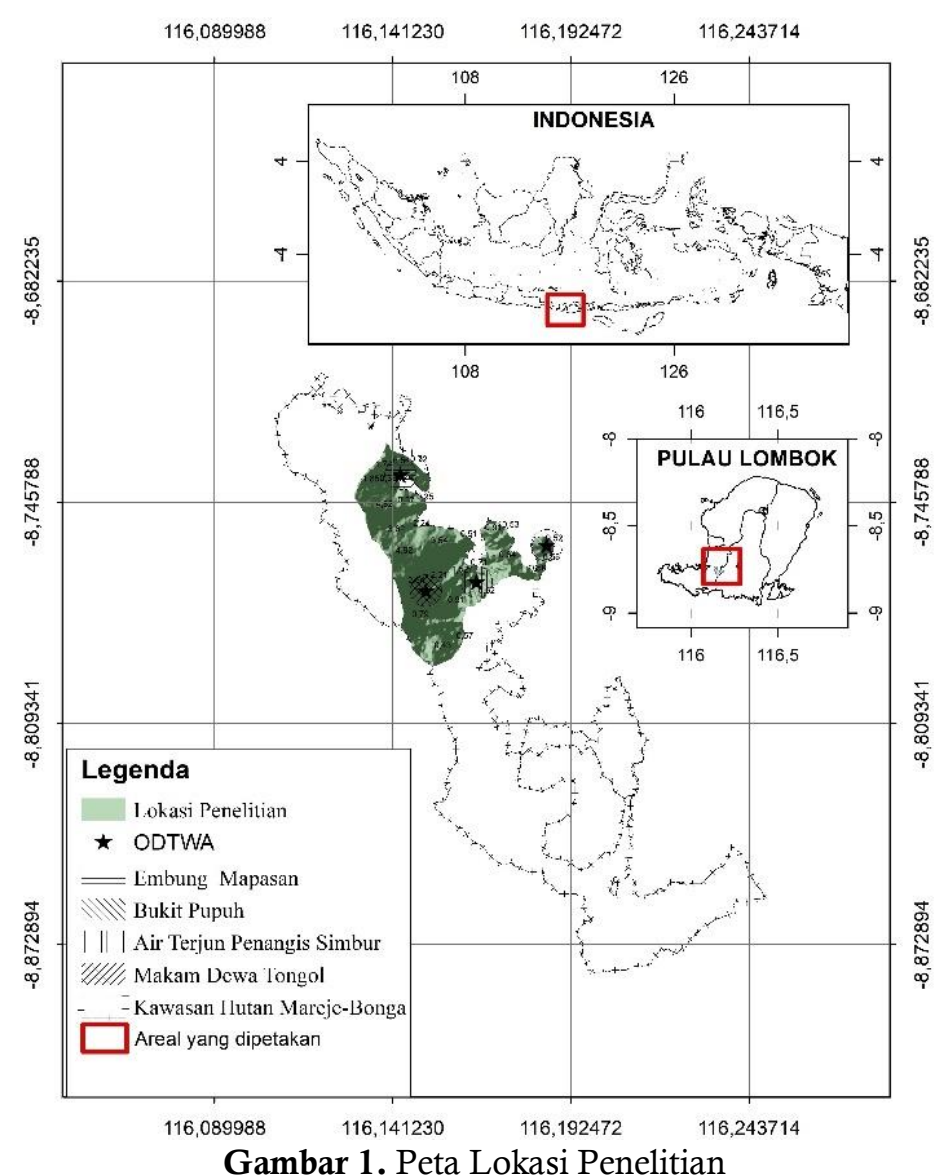

Penelitian ini dilakukan dengan menggunakan metode penelitian deskriptif kuantitatif, yaitu penelitian yang menggambarkan suatu fakta yang terjadi pada masa sekarang sebagai pusat perhatian dengan apa adanya melalui serangkaian proses pengumpulan data, analisis data, penarikan 
kesimpulan dan pelaporan yang menerapkan kaidah kaidah statistika secara obyektif (Sugiyono, 2012).

Jenis data yang digunakan dalam penelitian ini adalah data kuantitatif sekunder dan primer. Data sekunder meliputi: (1) Citra satelit Landsat-8 yang digunakan untuk menganalisis kondisi petutupan lahan; (2) Data jenis tanah berdasarkan peta tanah skala tinjau 1:250.000 dari Departemen Pertanian; (3) Citra satelit DEM SRTM-30 untuk menganalisis kelerengan, elevasi, daerah aliran sungai dan visibilitas; (3) Data curah hujan tahunan berdasarkan data iklim BMKG NTB; (5) Peta Jaringan jalan berdasarkan Peta Rupa Bumi Indonesia (RBI) dan Google Earth; dan (4) Data kunjungan wisatawan tahun 2018-2019 di setiap ODTWA yang ada di KHGMU. Data primer meliputi; diversitas pohon, daya tarik wisata alam, tekstur, permeabilitas dan drainase tanah serta lama kunjungan wisatawan.
Pengumpulan data sekunder dilakukan dengan mengkompilasi data dari berbagai sumber di instansi berwenang dan pustaka. Pengumpulan data primer aspek bio-fisik dilakukan dengan pengamatan lapangan pada 33 plot berukuran 20x20 m yang tersebar secara sistematis merata pada grid berukuran 500 x $1000 \mathrm{~m}$ (Gambar 2). Pada setiap plot dilakukan pengamatan daya tarik wisata menggunakan Pedoman Analisis Daerah Operasi Obyek dan Daya Tarik Wisata Alam (Arifin dan Utomo, 2018), pengamatan pohon penyusun ekosistem, pengamatan dan pengambilan sampel tanah untuk dianalisis di laboratorium. Pengamatan lama aktivitas wisatawan dilakukan dengan wawacara kepada 254 wisatawan yang datang ke setiap lokasi ODTWA di KHGMU.

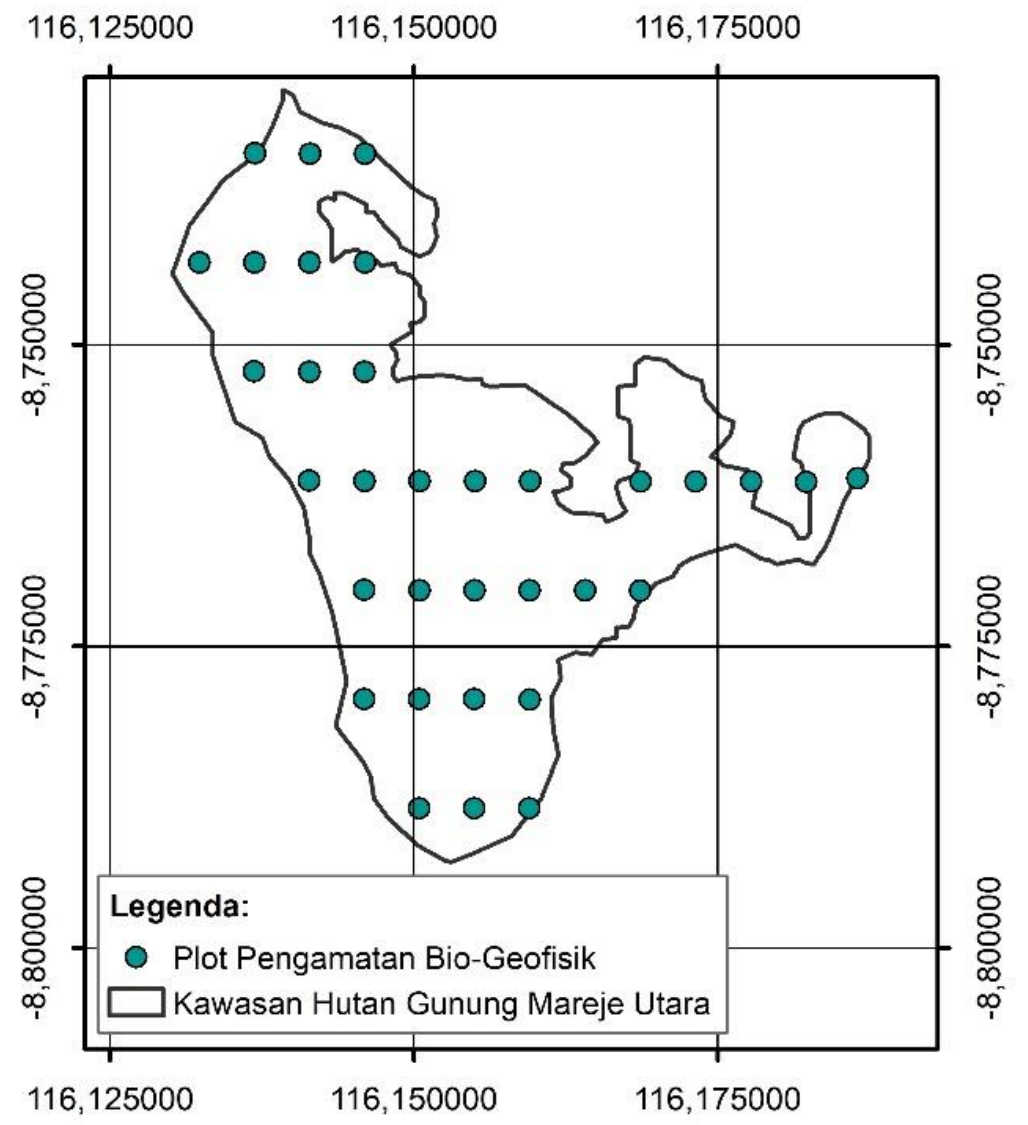

Gambar 2. Layout pengamatan plot aspek bio-geofisik

Nilai indeks diversitas pohon dihitung dengan metode Shanon-Wiener (Wiryanto et al., 2017). Nilai tekstur dan permeabilitas tanah dihitung berdasarkan analisis laboratorium terhadap sampel tanah, sedangkan drainase diamati langsung di lapangan. Nilai daya tarik wisata distandarkan, yaitu membagi nilai hasil pengamatan dengan nilai skor maksimum jika semua unsur daya tarik terpenuhi. Pada semua data hasil pengamatan lapangan dilakukan interpolasi spasial dan menyimpannya dalam format data raster dengan ukuran pixel 30x30 m sesuai kebutuhan analisis kesesuaian lahan untuk pengembangan ekowisata.
Kriteria dan indikator (K\&I) kesesuaian lahan disusun dengan menggunakan analisis multi kriteria (AMK) dan Analitical Hierarchy Process (AHP) (Sandhyavitri dan Ichsan, 2014). Proses AMK-AHP melibatkan 5 pakar terkait pengelolaan ekowisata di KHGMU selama pengamatan di lapangan dan studi literatur. Pada beberapa kriteria dan indikator yang belum memiliki nilai kelas kesesuaian, maka nilai kelas kesesuaian disusun berdasarkan analisis quantile yaitu dengan membagi data menjadi 4 kelas yang proporsinya sama (Lopez et al., 2017) (Tabel 1). 
Tabel 1. Kriteria dan indikator (K\&I) yang disusun dengan AMK dan kompilasi berbagai sumber

\begin{tabular}{|c|c|c|c|c|c|c|c|}
\hline \multirow{2}{*}{$\begin{array}{l}\text { Kriteria } \\
\text { (K) }\end{array}$} & \multirow{2}{*}{$\begin{array}{l}\text { Indikator } \\
\text { (I) }\end{array}$} & \multirow[t]{2}{*}{ Unit } & \multicolumn{4}{|c|}{ Kelas Kesesuaian Lahan Untuk Ekowisata } & \multirow{2}{*}{$\begin{array}{l}\text { Sumber } \\
\text { Pustaka }\end{array}$} \\
\hline & & & $\begin{array}{l}\text { Sesuai } \\
\text { (S1) }\end{array}$ & $\begin{array}{l}\text { Sesuai } \\
\text { Sedang } \\
\text { (S2) }\end{array}$ & $\begin{array}{l}\text { Sesuai } \\
\text { Marginal } \\
\text { (S3) }\end{array}$ & $\begin{array}{c}\text { Tidak } \\
\text { Sesuai } \\
(\mathrm{N})\end{array}$ & \\
\hline \multirow[t]{2}{*}{$\begin{array}{l}\text { Keindahan } \\
\text { Landskap }\end{array}$} & Daya Tarik & $\%$ & $>85$ & $82-84,9$ & $80-81.9$ & $<80$ & $\begin{array}{c}\text { Analisis quantile } \\
\text { (Lopez et al., 2017) }\end{array}$ \\
\hline & Visibilitas & $\begin{array}{l}\text { Inde } \\
x\end{array}$ & $7-15$ & $4-6$ & $0-3$ & 0 & $\begin{array}{l}\text { Bunruamkaew and } \\
\text { Murayama (2011) }\end{array}$ \\
\hline \multirow{2}{*}{$\begin{array}{c}\text { Kealamian } \\
\text { Lanskap/ } \\
\text { Wildlife }\end{array}$} & $\begin{array}{l}\text { Penutupan } \\
\text { hutan }\end{array}$ & $\%$ & $>84 \%$ & $82-84 \%$ & $80-82 \%$ & $<80 \%$ & Bali et al. (2015) \\
\hline & $\begin{array}{l}\text { diversitas } \\
\text { pohon }\end{array}$ & $\begin{array}{l}\text { Inde } \\
x\end{array}$ & $>2,70$ & $\begin{array}{l}2.35- \\
2,69\end{array}$ & $2.00-2.34$ & $<2.00$ & $\begin{array}{c}\text { Analisis quantile } \\
\text { (Lopez et al., 2017) }\end{array}$ \\
\hline \multirow{4}{*}{$\begin{array}{c}\text { Faktor } \\
\text { Pembatas } \\
\text { Aspek } \\
\text { Geofisik } \\
\text { Lahan }\end{array}$} & $\begin{array}{l}\text { Tekstur } \\
\text { Tanah }\end{array}$ & Kelas & $\begin{array}{l}\text { Lempung } \\
\text { Berdebu }\end{array}$ & $\begin{array}{l}\text { Lempung } \\
\text { Berpasir }\end{array}$ & $\begin{array}{l}\text { Pasir } \\
\text { Berlemp } \\
\text { ung }\end{array}$ & $\begin{array}{l}\text { Pasir, } \\
\text { Pasir } \\
\text { Berlem } \\
\text { pung }\end{array}$ & Bali et al. (2015) \\
\hline & Kelerengan & $\%$ & $0-5 \%$ & $5-25 \%$ & $25-35 \%$ & $>35 \%$ & $\begin{array}{l}\text { Bunruamkaew and } \\
\text { Murayama (2011) }\end{array}$ \\
\hline & Elevasi & $\mathrm{mpl}$ & $>300$ & $200-300$ & $100-200$ & $<100$ & $\begin{array}{l}\text { Bunruamkaew and } \\
\text { Murayama (2011) }\end{array}$ \\
\hline & $\begin{array}{l}\text { Curah } \\
\text { Hujan }\end{array}$ & $\begin{array}{c}\mathrm{mm} / \\
\text { th }\end{array}$ & $<1540$ & $\begin{array}{l}1540- \\
1632\end{array}$ & $\begin{array}{c}16320- \\
1729\end{array}$ & $>1729$ & $\begin{array}{l}\text { Analisis quantile } \\
\text { (Lopez et al, 2017) }\end{array}$ \\
\hline \multirow[t]{3}{*}{ Aksesibilitas } & $\begin{array}{l}\text { Jarak dari } \\
\text { Jalan }\end{array}$ & $\mathrm{m}$ & $<500 \mathrm{~m}$ & $500-750 \mathrm{~m}$ & $\begin{array}{c}750- \\
1000 \mathrm{~m}\end{array}$ & $\underset{1000 \mathrm{~m}}{>}$ & Bali at al. (2015) \\
\hline & $\begin{array}{l}\text { Jarak dari } \\
\text { mata air }\end{array}$ & $\mathrm{m}$ & $<500 \mathrm{~m}$ & $500-750 \mathrm{~m}$ & $\begin{array}{c}750- \\
1000 \mathrm{~m}\end{array}$ & $\begin{array}{c}>1000 \\
m\end{array}$ & Bali at al., (2015) \\
\hline & $\begin{array}{c}\text { Jarak dari } \\
\text { pemukiman }\end{array}$ & $\mathrm{m}$ & $<500 \mathrm{~m}$ & $\begin{array}{c}500- \\
1000 \mathrm{~m}\end{array}$ & $\begin{array}{l}1000- \\
5000 \mathrm{~m}\end{array}$ & $\begin{array}{c}>5000 \\
\mathrm{~m}\end{array}$ & Bali at al. (2015) \\
\hline
\end{tabular}

Setelah nilai bobot dan rating tiap K\&I analisis matching metode weighted linear combination didapatkan, tahapan analisis dilanjukan dengan $\quad$ (WLC) menggunakan software Arcgis 10.7 (Gambar 3).
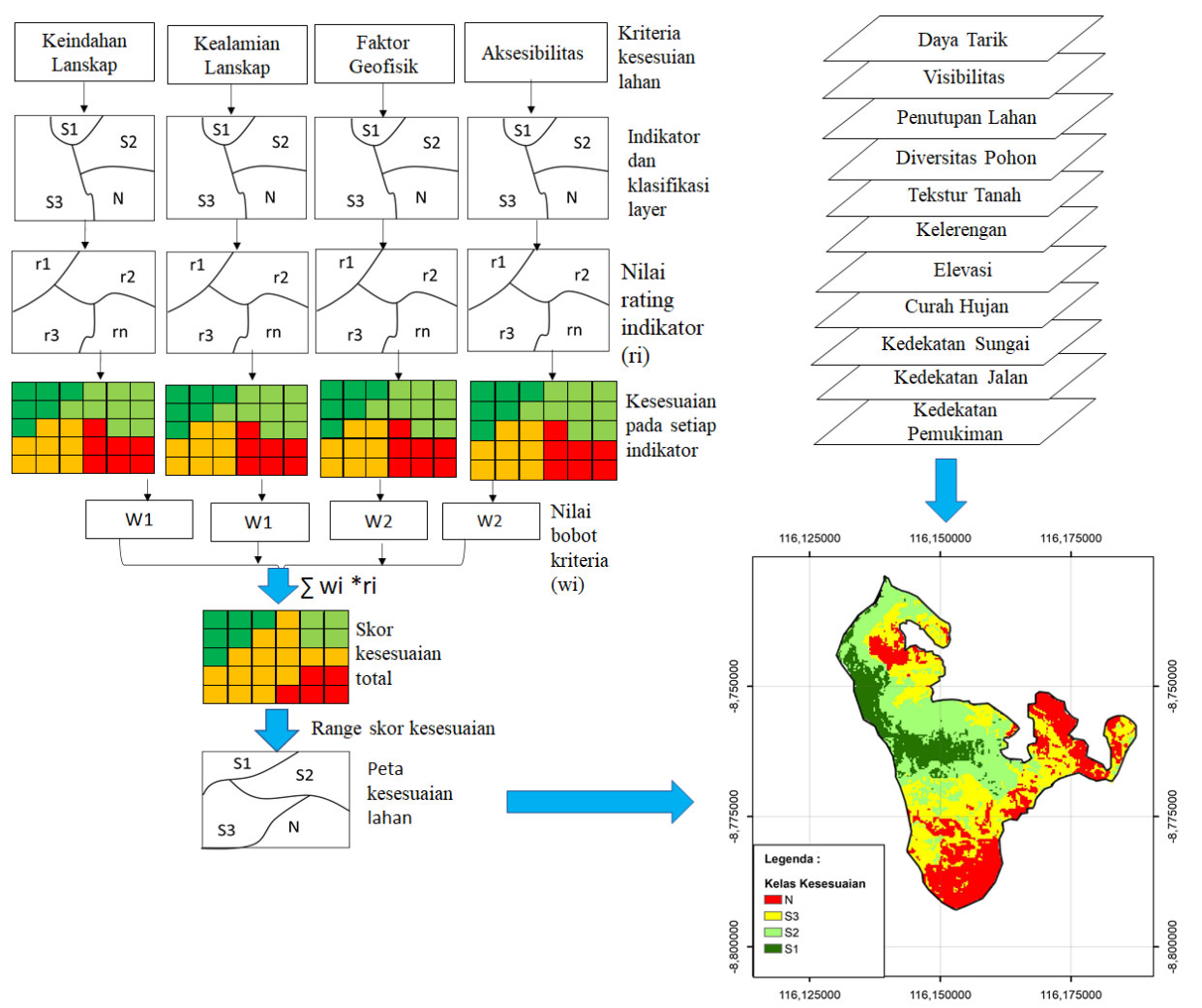

Gambar 3. Tahapan analisis kesesuaian lahan metode WLC di KHGMU (Bunruamkaew and Murayama, 2011) 
Penentuan derajat kesesuaian lahan dilakukan dengan analisis quantile yaitu membagi sebaran data menjadi 4 kelas, dimana nilai skor maksimal yang akan dihasilkan adalah 1 (Tabel 2). Analisis faktor

Tabel 2. Rentang nilai kesesuaian lahan hasil WLC

\begin{tabular}{ccc}
\hline $\begin{array}{c}\text { Kelas } \\
\text { Kesesuaian }\end{array}$ & $\begin{array}{c}\text { Rentang } \\
\text { Nilai }\end{array}$ & $\begin{array}{c}\text { Derajat } \\
\text { Kesesuaian }\end{array}$ \\
\hline S1 & $0.75-1$ & Sengat Sesuai \\
S2 & $0.5-0.75$ & Cukup Sesuai \\
S3 & $0.25-0.5$ & Sesuai Marginal \\
N & $<0.25$ & Tidak Sesuai \\
\hline
\end{tabular}

Sumber: Pengolahan data primer (2020)

Penilaian daya dukung lingkungan dilakukan ngan Metode Douglas (Zacarias et al., 2011) pada kelas lahan yang sesuai $(\mathrm{S} 1+\mathrm{S} 2+\mathrm{S} 3)$ untuk pengembangan ekowisata berdasarkan hasil analisis kesesuaian lahan. Evaluasi kesesuaian dan daya dukung lingkungan menggunakan t-test dengan Software SPSS 26, yaitu membandingkan antara luas kelas lahan yang sesuai hasil WLC dengan luas pemanfaatan lahan actual. Demikian juga perbandingan antara nilai daya dukung lingkungan dengan rata-rata jumlah kunjungan wisatawan aktual yang datang ke KHGMU.

\section{HASIL DAN PEMBAHASAN}

Berdasarkan hasil interpretasi citra satelit Landsat-8 yang di unduh pada tanggal 4 April 2019, menujukkan bahwa 52\% tutupan lahan di KHGMU berupa lahan hutan kering primer dan sekunder. Tekanan Penduduk terhadap lahan hutan tergolong tinggi, hal ini ditandai dengan adanya kawasan pemukiman seluas 25,6 Ha dan pembukaan lahan hutan untuk lahan sawah seluas 4,6 Ha. Pengembangan ekowisata menjadi salah satu upaya untuk mengurangi tekanan penduduk terhadap lahan hutan dan meningkatkan keanekaragaman hayati. Pada hutan lahan kering primer jenis pohon didominasi oleh Voacanga grandifolia, Cordia myxa L. dan Pterospermum javanicum. Jenis pohon penyusun hutan lahan kering sekunder didominasi oleh Tectona grandis, Dalbergia latifolia serta Swietenia mahagoni. Berdasarkan pengamatan lapangan diketahui bahwa ancaman menurunnya keanekaragam hayati di KHGMU akan semakin tinggi mengingat masih maraknya praktek perambahan lahan.

Jenis Tanah di lokasi penelitian terdiri atas jenis tanah inceptisol (Typic Haplustepts dan Typic Eutrudepts ) dan entisol (Lithic Ustorthents dan Typic Ustorthents). Berdasarkan hasil analisis laboratorium diketahui bahwa jenis tanah Typic Haplustepts memiliki kelas tekstur lempung berdebu dengan permeabilitas dan drainase yang lambat memiliki proporsi terluas yaitu sebesar 53,4\% dari luas seluruh kawasan. Diikuti oleh jenis tanah Typic Eutrudepts bertekstur lempung berpasir (proporsi $=29,6 \%$ ), Lithic Ustorthents bertekstur lempung berpasir (proporsi=16,1\%) dan Typic Ustorthents bertekstur pasir atau pasir berlempung (proporsi=0,9\%). Hasil analisis DEM SRTM-30 yang kunci kesesuaian lahan dilakukan dengan metode generalized boosted regression model atau GBM (Friedman, 2002) menggunakan package gbm pada software R-Statisctics.

di unduh pada tanggal 4 April 2019 menunjukkan bahwa $54 \%$ dari total luas kawasan mimiliki kelerengan yang curam (kelerengan $>35 \%$ ) dimana lebih dari $60 \%$ berada pada elevasi $>300$ mdpl. Sekitar $44 \%$ dari luas kawasan berada kelerengan sedang (5$35 \%$ ) dan sisanya sebesar $2.2 \%$ berada pada kelas kelerengan datar $(<5 \%)$. Kondisi iklim di wilayah KPHL Tastura termasuk iklim tropis dengan curah hujan berkisar antara $1.000-2.500 \mathrm{~mm} /$ tahun. Berdasarkan hasil analisis data curah hujan BMKG Provinsi NTB, KHGMU memiliki Tipe iklim D (sedang) dalam sistem klasifikasi iklim Schmidt Ferguson, yaitu dengan nilai perbandingan rata-rata bulan kering dan rata-rata bulan basah (Q) berkisar $0,60<\mathrm{Q}<1,00$ dan Curah hujan tahunan berkisar antara $1460-1847 \mathrm{~mm} /$ tahun.

\section{Penilaian Kesesuaian Lahan untuk Pengembangan Ekowisata}

Berdasarkan Analisis AMK-AHP, dengan melibatkan 5 pakar dan praktisi yang terkait dengan pengelolaan ekowisata di KHGMU dihasilkan nilai rating dan bobot K\&I kesesuaian lahan yang ditunjukkan dalam Tabel 3 dan 4. Faktor geofisik khusunya tanah, kelerengan dan curah hujan dalam analisis AMK-AHP. Hal ini disebabkan karena Pulau Lombok berada diantara dua jalur gempa bumi yaitu Australia Plate dan Flores Back Arc Thrust Fault, juga mempertimbangkan ekosistem KHGMU yang merupakan ekosistem pegunungan yang berlereng.

Untuk menjaga keselamatan pengunjung dari ancaman tanah longsor dan dampak negatif dari kegiatan ekowisata seperti meningkatnya erosi tanah, maka aspek geofisik lebih mendapatkan perhatian dalam pengembangan ekowisata di KHGMU (Tabel 4). Bobot dan rating derajat kelas kesesuaian dari seluruh K\&I disusun berdasarkan analisis AHP dan quantile ditunjukkan pada Tabel 3.

Tabel 3. Bobot dan rating derajat kelas kesesuaian berdasarkan AHP

\begin{tabular}{ccc}
\hline $\begin{array}{c}\text { Derajat } \\
\text { Kelas Kesesuian }\end{array}$ & Bobot $\left(\mathbf{w}_{\mathbf{i}}\right)$ & $\begin{array}{c}\text { Rating } \\
\left(\mathbf{r}_{\mathbf{i}}\right)\end{array}$ \\
\hline R1 & 0.47 & 1.000 \\
R2 & 0.28 & 0.595 \\
R3 & 0.16 & 0.346 \\
RN & 0.10 & 0.206 \\
CI & 0.012 & \\
CR & $0.013^{*}$ & \\
\hline
\end{tabular}

* Nilai CR < 5\% menunjukkan bahwa bobot yang ditetapkan telah konsisten 
Tabel 4. Bobot K\&I kesesuaian lahan berdasarkan AMK dan AHP

\begin{tabular}{|c|c|c|c|c|c|}
\hline $\begin{array}{l}\text { Kriteria } \\
\text { (K) }\end{array}$ & $\begin{array}{c}\text { Bobot } \\
\text { Kriteria(wk) }\end{array}$ & $\begin{array}{l}\text { Indikator } \\
\text { (I) }\end{array}$ & $\begin{array}{c}\text { Bobot } \\
\text { Indikator } \\
(w p)\end{array}$ & CI & CR \\
\hline Keindahan & 0,227 & Daya Tarik & 0,114 & 0,000 & $0,000^{*}$ \\
\hline Landskap & & Visibilitas & 0,114 & & \\
\hline \multirow[t]{2}{*}{$\begin{array}{c}\text { Kealamian Landskap/ } \\
\text { Wildlife }\end{array}$} & 0,227 & $\begin{array}{l}\text { Penutupan } \\
\text { Lahan }\end{array}$ & 0,114 & 0,000 & $0,000^{*}$ \\
\hline & & $\begin{array}{c}\text { Keaneragaman } \\
\text { Jenis }\end{array}$ & 0,114 & & \\
\hline \multirow[t]{4}{*}{ Faktor Geofisik } & 0,423 & Jenis Tanah & 0,180 & 0,016 & $0,018^{*}$ \\
\hline & & Kelerengan & 0,098 & & \\
\hline & & Elevasi & 0,063 & & \\
\hline & & Curah Hujan & 0,082 & & \\
\hline \multirow[t]{3}{*}{ Aksesibilitas } & 0,123 & Jarak Dari Jalan & 0,041 & 0,000 & 0,000 * \\
\hline & & $\begin{array}{c}\text { Jarak Dari Mata } \\
\text { Air }\end{array}$ & 0,041 & & \\
\hline & & $\begin{array}{l}\text { Jarak Dari } \\
\text { Pemukiman }\end{array}$ & 0,041 & & \\
\hline CI & 0.003 & & & & \\
\hline CR & $0.004^{*}$ & & & & \\
\hline
\end{tabular}

Setelah nilai bobot dan rating setiap K\&I serta rentang nilai kesesuaian lahan tersusun, tahapan analisis dilanjutkan dengan analisis spasial menggunakan metode weighted linear combination, yaitu mengalikan seluruh nilai rating dan bobot setiap satuan lahan dengan menggunakan software Argis 10.7 (Gambar 4).
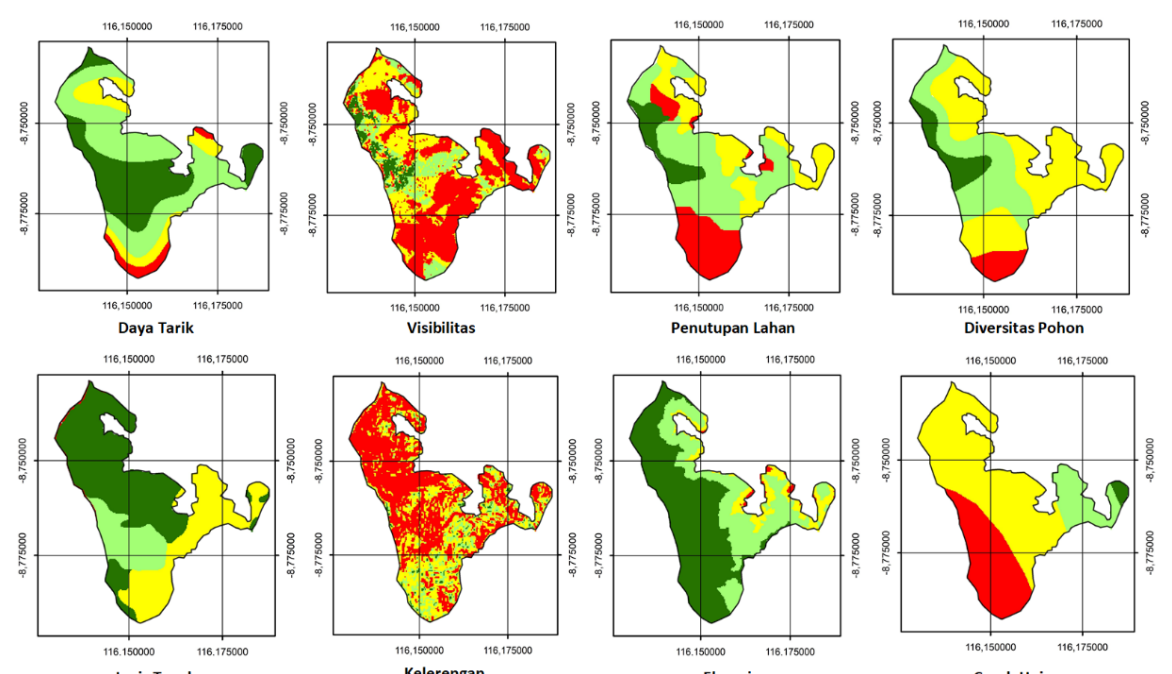

Jenis Tanah
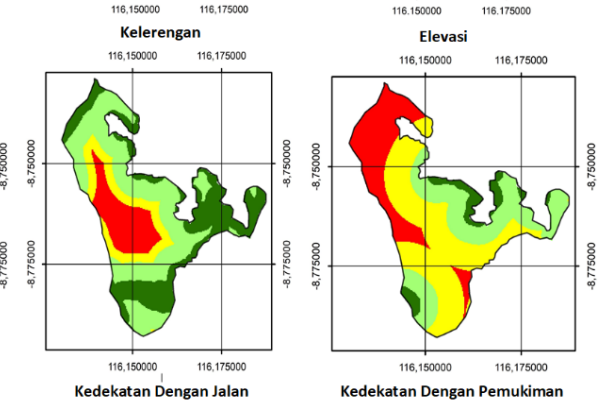

Curah Hujan

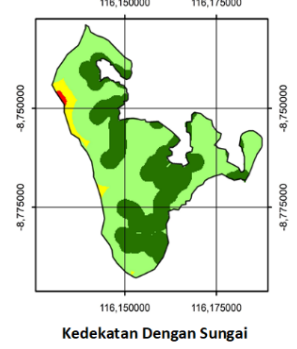

Kedekatan Dengan Jalan

Kedekatan Dengan Pemukiman

Gambar 4. Nilai rating setiap indikator kesesuaian lahan dalam format data raster yang telah dikelaskan

Berdasarkan hasil analisis matching menggunakan metode $W L C$ diketahui bahwa luas total dari lahan yang sesuai untuk pengembangan ekowisata di KHGMU adalah seluas $1.235,2 \mathrm{Ha}$ atau $75,8 \%$ dari total kawasan hutan yang ada. Kelas lahan yang sesuai terdiri atas 211,6 $\mathrm{Ha}(13,0 \%)$ pada kelas sangat sesuai
(S1), 495,1 Ha (30,4\%) cukup sesuai (S1) dan 528,5 Ha $(32,4 \%)$ sesuai marginal. Terdapat sekitar 394,2 Ha $(24,2 \%)$ merupakan kelas lahan yang tidak sesuai untuk dikembangkan menjadi kawasan ekowisata (Gambar 5 dan Tabel 5). 


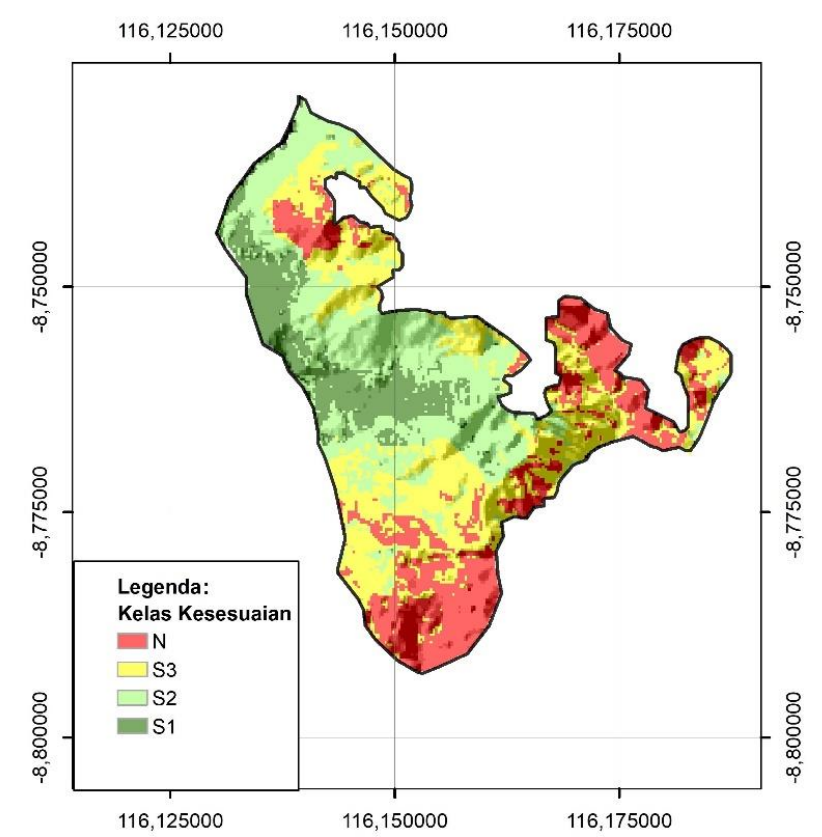

Gambar 5. Peta arahan kesesuaian lahan untuk pengembangan ekowisata di KHGMU

Tabel 5. Distribusi areal KHGMU berdasarkan kelas kesesuaian lahan untuk pengembangan ekowisata

\begin{tabular}{ccc}
\hline $\begin{array}{c}\text { Kelas } \\
\text { Kesesuian }\end{array}$ & $\begin{array}{c}\text { Luas } \\
\text { (Ha) }\end{array}$ & $\begin{array}{c}\text { Persentase } \\
\mathbf{( \% )}\end{array}$ \\
\hline S1 & 211,6 & 13,0 \\
S2 & 495,1 & 30,4 \\
S3 & 528,5 & 32,4 \\
N & 394,2 & 24,2 \\
Total & 1629,3 & 100,0 \\
\hline
\end{tabular}

Sumber: pengolahan data primer (2020)

Berdasarkan analisis faktor menggunakan genarilized boosted regression Model (GBM). Diketahui bahwa faktor tanah menjadi faktor yang paling berpengaruh dengan nilai RI sebesar $21,4 \%$, diikuti keanekaragaman pohon dengan RI sebesar $14,7 \%$, visibilitas sebesar $14.2 \%$ dan daya tarik wisata sebesar 9.1\% (Gambar 6). Tingginya proporsi lahan yang sesuai untuk pengembangan ekowisata di KHGMU disebabkan karena persentase luas lahan dengan tanah bertekstur lempung lebih banyak dibandingkan tanah yang bertekstur pasir. Kondisi ini akan mampu mendukung lebih banyak kegiatan ekowisata yang menjamin keselamatan baik kepada pengunjung maupun kepada ekosistem yang ada di KHGMU. Tanah memiliki pengaruh yang besar dalam menentukan kesesuaian pengembangan ekowisata karena tanah dengan tekstur yang baik akan mampu memberikan ruang tumbuh yang optimal kepada tumbuhan untuk meningkatkan keanekargaman hayati dan mendukung aktivitas wisatawan secara optimal (Hardjowigeno dan Widiatmaka, 2018). Selain faktor tanah, proporsi lahan dengan penutupan hutan yang memiliki keanekaragaman jenis pohon yang ada di KHGMU juga lebih luas dibandingkan dengan lahan tak bervegetasi. Kondisi ini akan meningkatkan daya tarik ekowisata. Namun pengembangan ekowisata juga harus mampu melakukan zonasi atau koreksi terhadap intensitas pemanfaatan dengan memperhitungkan faktor pembatas keanekaragaman hayati (Lucianti et al., 2013). Demikian juga proporsi lahan di KHGMU dengan elevasi lebih dari $300 \mathrm{~m}$ yang lebih luas akan memberikan visibilitas yang lebih baik kepada wisatawan untuk menikmati keindahan panorama alam secara lebih luas. Hasil analisis ini menjelaskan bahwa faktor yang esensial yang menentukan kawasan hutan dapat dikembangkan menjadi obyek wisata alam di KHGMU meliputi tanah, keanekaraagaman jenis, visibilitas dan daya tarik. 


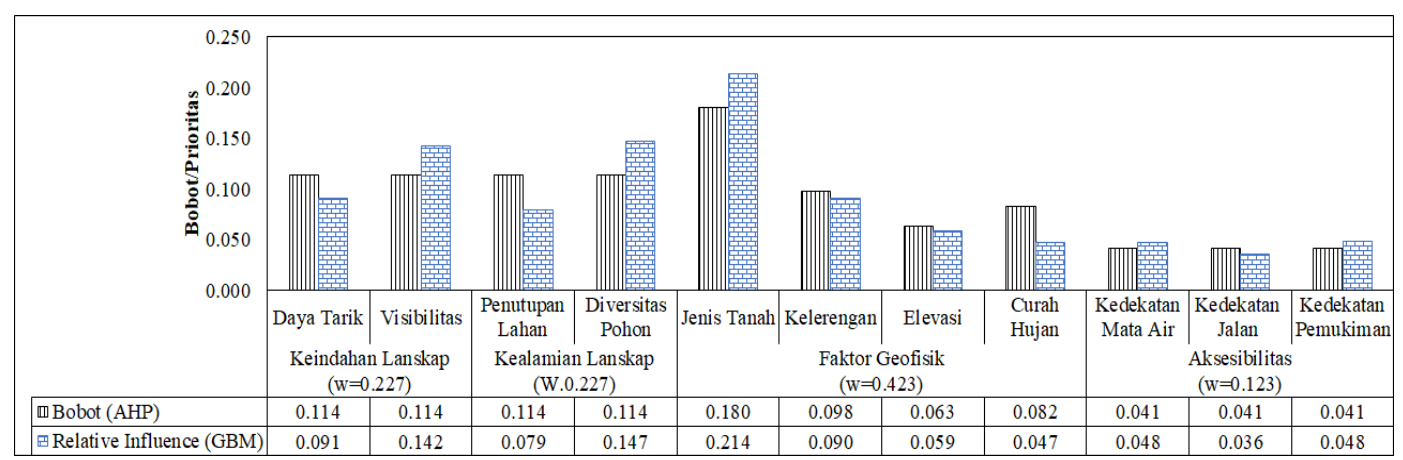

Gambar 6. Nilai bobot berdasarkan AHP dan relative influence (RI) setiap indikator kesesuaian lahan berdasarkan analisis GBM

Berdasarkan hasil analisis korelasi diketahui bahwa terdapat hubungan erat antara nilai bobot dari setiap indikator dengan nilai relative influence (RI). Nilai RI menjelaskan pengaruh nilai rating terhadap skor total kesesuaian lahan yang dihasilkan dalam analisis WLC. Hubungan antara nilai bobot dari setiap indikator dengan dan relative influence sangat kuat,

dengan $R$-Square $=0,81$ atau $>0.60$ dan $p$ value $=0.000146$ atau $<0.05$. Hal ini mencerminkan bahwa bobot atau prioritas dari setiap K\&I yang digunakan dalam analisis kesesuaian lahan untuk pengembangan ekowisata di KHGMU telah mampu menjelaskan variasi skor total kesesuaian lahan yang dihasilkan (Gambar 7).

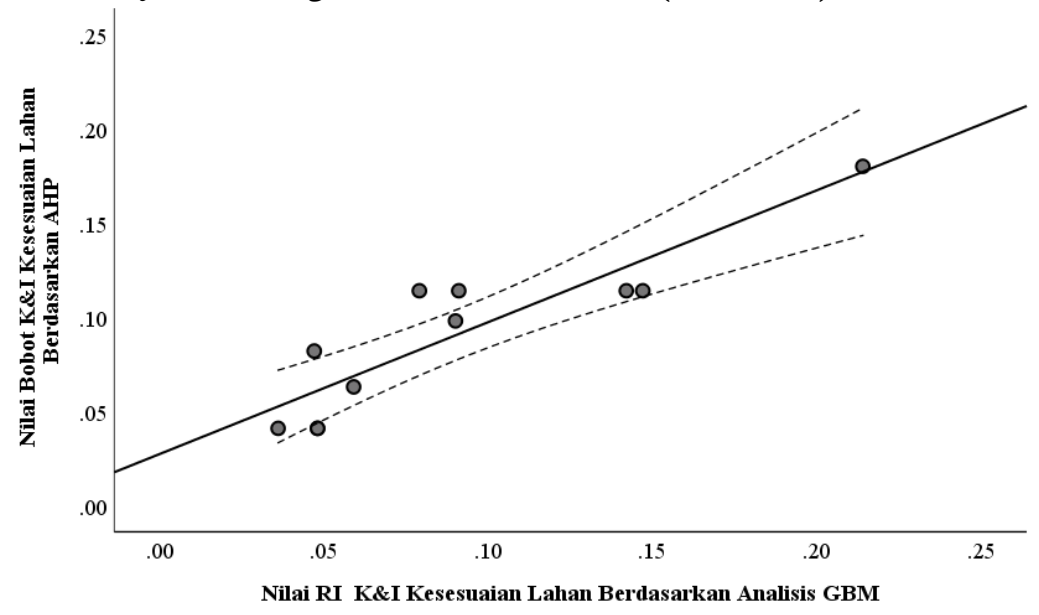

Gambar 7. Grafik hubungan antara Nilai RI-GBM dan bobot dari indikator kesesuaian lahan berdasarkan AMK-AHP

Evaluasi Kesesuaian Lahan untuk Pengembangan Ekowista

Hasil analisis kesesuaian lahan menunjukkan bahwa sebaran kelas kesesuaian lahan di KHGMU bervariasi diantara setiap ODTWA. Secara umum $86,3 \%$ dari lahan yang saat ini telah dikembangkan menjadi kawasan wisata telah berada pada kelas lahan yang sesuai. Namun demikian terdapat 13,7\% lahan yang telah dikembangkan berada pada kelas yang yang tidak sesuai. Pada lokasi ODTWA Makam Dewa Tongol proporsi luas S1, S2 dan S3 lebih luas dibandingkan dengan ODTWA lainnnya, diikuti oleh Air Terjun Penangis Simbur dan Embung Mapasan.

Pada lokasi ODTWA Bukit Pupuh memiliki proporsi luas lahan yang sesuai untuk pengembangan ekowisata lebih sedikit dibandingkan ODTWA lainnya (Tabel 6). Tingginya luas lahan yang sesuai untuk pengembangan ekowisata di Makam Dewa
Tongol disebabkan karena proporsi faktor kunci pendukung pengembangan ekowisata berupa proporsi tanah berlempung, keanekaragaman jenis pohon, visibilitas dan daya tarik wisata yang mendukung kegiatan ekowisata lebih luas dibandingkan ODTWA Lainnya.

Berdasarkan evaluasi lahan menggunakan one mean $t$ test diketahui bahwa rata-rata pengunaan lahan aktual pada kelas yang sesuai lebih rendah dibandingkan dengan luas lahan yang potensial untuk diembangkan menjadi ODTWA. Hal ini menunjukkan bahwa pemanfaatan lahan di KGMU tidak melebihi potensi kelas lahan yang sesuai untuk dikembangkan menjadi daerah tujuan ekowisata. Sehingga dapat dijelaskan bahwa pengembangan ekowisata di KHGMU telah memenuhi aspek kesesuaian lahan ( Tabel 6 dan Gambar 8). 
Tabel. 6. Distribusi kesesuaian lahan di setiap ODTWA

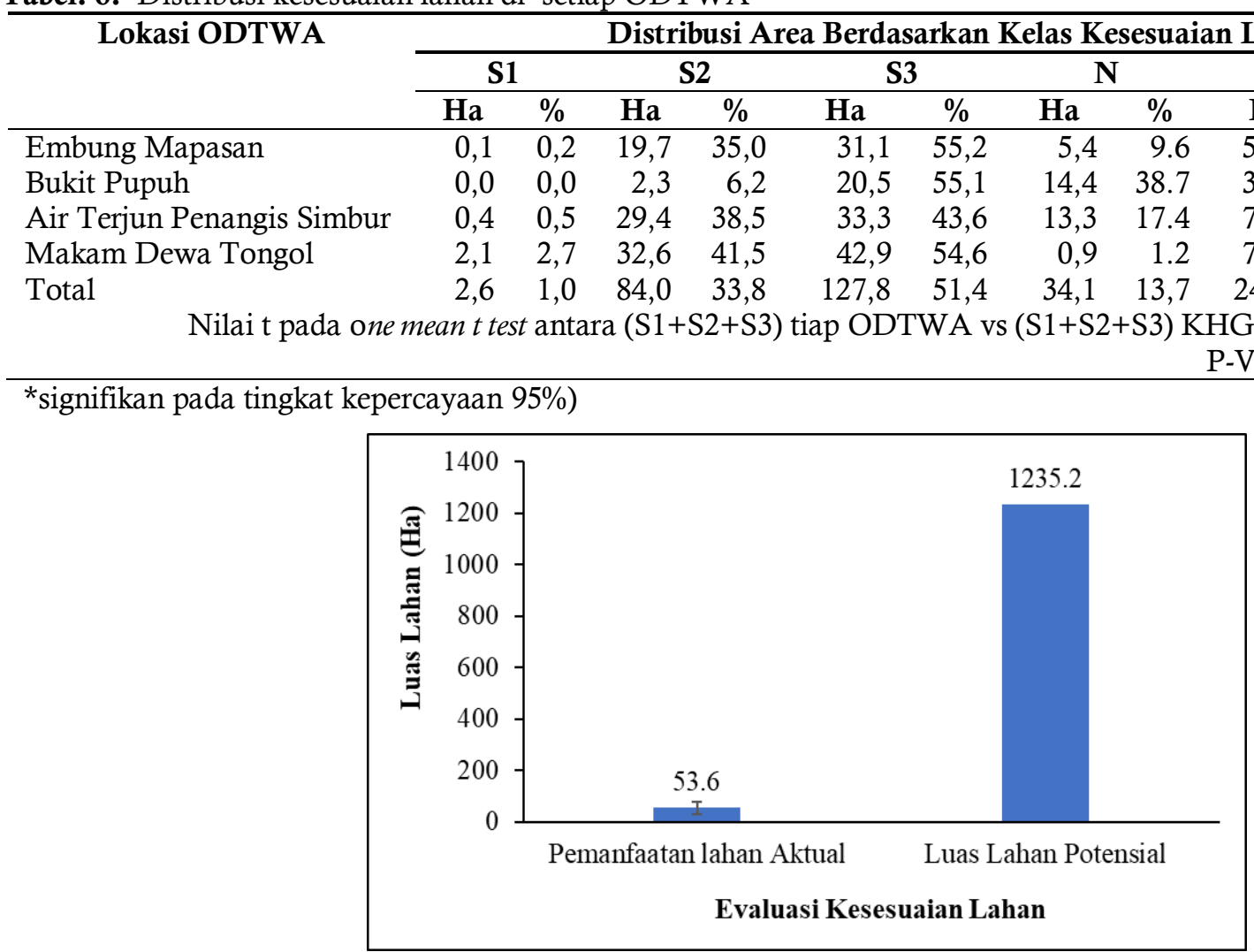

Gambar 8. Grafik evaluasi kesesuaian lahan

Penilaian dan Evaluasi Daya Dukung Lingkungan untuk Pengembangan Ekowisata

Perhitungan daya dukung lingkungan untuk pengembangan ekowisata di KHGMU dilakukan pada kelas lahan yang sesuai untuk pengembangan ekowisata, yaitu kelas lahan S1, S2 dan S3 yang dihasilkan berdasarkan analisis kesesuaian lahan. Tahap awal perhitungan daya dukung lingkungan dilakukan dengan menganalisis physical carrying capacity (PCC). Dalam analisis PCC, luas kawasan hutan S1, S2 dan S3 pada setiap OTDWA dijumlah sebagai dasar perhitungan luasan efektif kawasan ekowisata (A). Jumlah kunjungan wisatawan per hari dihitung dengan membagi rata-rata kunjungan per tahun selama tahun 2018-2019 dengan 365 hari. Nilai luas areal optimum (B) yang dibutuhkan oleh seorang wisatawan untuk memperoleh kepuasan wisata pada jenis wisata piknik yaitu sebesar $65 \mathrm{~m}^{2}$ (Fandeli dan Muhammad, 2009).
Lama aktivitas wisatawan (T) dihitung berdasarkan rata-rata lama aktivitas wisata hasil wawancara terhadap wisatawan. Jumlah jam layanan wisata (ST) di setiap ODTWA dihitung berdasarkan hasil wawancara dengan pengelola KHGMU dengan jam operasional layanan selama 9 jam/hari. Faktor koreksi rotasi (Rf) dihitung dengan membagi jumlah layanan wisata dengan rata-rata lama kunjungan wisatawan.

Hasil analisis PCC menunjukkan bahwa bahwa KHGMU memiliki potensi daya dukung fisik mencapai 475.077 wisatawan/hari. Daya dukung terbesar berada pada lokasi ODTWA Air Terjun Penangis Simbur yang mampu melayani kunjungan wisatawan mencapai 29.123 wisatawan/hari. Lokasi ODTWA Bukit Pupuh memiliki nilai PCC terendah, yaitu mampu melayani 7.366 wisatawan/hari (Tabel 7).

Tabel 7. Hasil perhitungan PCC di KHGMU

\begin{tabular}{|c|c|c|c|c|c|c|c|}
\hline ODTWA & $\begin{array}{c}\text { Luas } \\
\text { Lahan } \\
\mathrm{S} 1+\mathrm{S} 2+\mathrm{S} 3 \\
(\mathrm{~m} 2)\end{array}$ & $\begin{array}{c}\text { Jumlah } \\
\text { Wisatawan } \\
\text { (wisatawan } \\
\text { /hari) }\end{array}$ & $\begin{array}{c}\mathrm{B} \\
(\mathrm{m} 2)\end{array}$ & $\begin{array}{c}\mathrm{T} \\
\text { (Jam } \\
\text { /wisata } \\
\text { wan) }\end{array}$ & $\begin{array}{c}\mathrm{ST} \\
\text { (Jam } \\
\text { /Hari) }\end{array}$ & $\begin{array}{c}\mathrm{Rf} \\
\text { (wisatawan } \\
\text { /hari) }\end{array}$ & $\begin{array}{c}\text { PCC } \\
\begin{array}{c}\text { (wisatawan/ } \\
\text { hari) }\end{array}\end{array}$ \\
\hline Embung Mapasan & 509.000 & 3 & 65 & 3,0 & 9,0 & 3,0 & 23.492 \\
\hline Bukit Pupuh & 228.000 & 22 & 65 & $4 ., 2$ & 9,0 & 2,1 & 7.366 \\
\hline Air Terjun Penangis Simbur & 631.000 & 4 & 65 & 3,0 & 9,0 & 3,0 & 29.123 \\
\hline Makam Dewa Tongol & 776.000 & 2 & 65 & 4,5 & 9,0 & 2,0 & 23.877 \\
\hline $\begin{array}{l}\text { Seluruh Kawasan Gunung } \\
\text { Mareje }\end{array}$ & 12.352 .000 & 31 & 65 & 3,7 & 9,0 & 2,5 & 475.077 \\
\hline
\end{tabular}

Sumber: pengolahan data primer (2020) 
Nilai PCC bukan merupakan nilai daya dukung sesungguhnya, karena belum memperhitungkan faktor pembatas. Untuk mengetahui daya dukung sebenarnya, dalam penelitian ini juga dihitung nilai real carrying capacity (RCC) yaitu mengalikan nilai PCC dengan faktor koreksi pembatas curah hujan, kelerengan, erodibilitas tanah dan diversitas pohon. Faktor koreksi curah hujan dihitung berdasarkan nilai rata-rata jumlah bulan basah dan bulan kering. Data iklim dari BMKG NTB menunjukkan bahwa rata-rata bulan basah di lokasi penelitian sebesar 7 bulan/tahun dan rata-rata bulan kering selama 5 bulan/tahun, sehingga didapat nilai $\mathrm{Q}=5 / 7=0,714$, sedangkan nilai Q maksimal untuk sistem klasifikasi iklim Schmidt dan Ferguson adalah 7 sehingga nilai koreksi curah hujan $=0.898$. Karena data detail bulan basah dan bulan kering hanya tersedia untuk seluruh Kabupaten Lombok Tengah, maka nilai koreksi curah hujan untuk seluruh lokasi OTDWA adalah sama. Perhitungan Faktor koreksi kelerengan dilakukan dengan menghitung rata-rata tertimbang kelas lereng di setiap
ODTWA dan nilai maksimum kelerengan $=100 \%$. Perhitungan faktor koreksi tanah dilakukan dengan menghitung nilai erodibilitas berdasarkan nilai tesktur dan permeabilitas tanah yang dihasilkan dari analisis laboratorium.

Hasil perhitungan nilai erodibilitas pada setiap jenis tanah dibagi dengan nilai maksimum dari erodibiltas tanah yaitu sebesar 0,64 (Ashari, 2013). Faktor koreksi diversitas pohon dihitung dengan membagi indeks diversitas di setiap lokasi ODTWA dengan nilai maksimum indeks Shannon-Wiener yaitu sebesar 3,5. Berdasarkan hasil analisis diketahui bahwa nilai RCC untuk seluruh KHGMU sebesar 65.547 wisatawan/hari atau $13,9 \%$ dari total PCC. Nilai RCC terbesar berada di lokasi ODTWA Embung Mapasan yang mampu menerima kunjungan wisatawan 4.378 Wisatawan/hari, sedangkan terendah adalah ODTWA Bukit Pupuh mampu menerima kunjugan wisatawan sebanyak 1.227 wisatawan/hari (Tabel 8).

Tabel 8: Perhitungan RCC untuk pengembangan ekowisata di KGMU

\begin{tabular}{|c|c|c|c|c|c|c|}
\hline \multirow[b]{2}{*}{ ODTWA } & \multirow[b]{2}{*}{$\begin{array}{c}\text { PCC } \\
\text { (wisatawan } \\
\text { /hari) }\end{array}$} & \multicolumn{4}{|c|}{ Factor Koreksi Pembatas } & \multirow[b]{2}{*}{$\begin{array}{c}\text { RCC } \\
\text { (wisatawan } \\
\text { /hari) }\end{array}$} \\
\hline & & $\begin{array}{l}\text { Curah } \\
\text { Hujan } \\
\text { (CF1) }\end{array}$ & $\begin{array}{c}\text { Kelerengan } \\
\text { (CF2) }\end{array}$ & $\begin{array}{l}\text { Erodibilitas } \\
\text { Tanah } \\
\text { (CF3) }\end{array}$ & $\begin{array}{l}\text { Diversitas } \\
\text { Pohon } \\
\text { (CF4) }\end{array}$ & \\
\hline $\begin{array}{l}\text { Embung } \\
\text { Mapasan }\end{array}$ & 23.492 & 0,898 & 0,681 & 0,683 & 0,446 & 4.378 \\
\hline Bukit Pupuh & 7.516 & 0,898 & 0,690 & 0,683 & 0,386 & 1.227 \\
\hline $\begin{array}{l}\text { Air Terjun } \\
\text { Penangis Simbur }\end{array}$ & 29.123 & 0,898 & 0,719 & 0,683 & 0,323 & 4.147 \\
\hline $\begin{array}{l}\text { Makam Dewa } \\
\text { Tongol }\end{array}$ & 23.877 & 0,898 & 0,670 & 0,652 & 0,234 & 2.194 \\
\hline $\begin{array}{l}\text { Seluruh Kawasan } \\
\text { Gunung Mareje }\end{array}$ & 475.078 & 0,898 & 0,693 & 0,678 & 0,327 & 65.547 \\
\hline
\end{tabular}

Sumber : Pengolahan data primer (2020)

Tahap akhir perhitungan daya dukung lingkungan adalah menghitung nilai effective carrying capacity (ECC). Yaitu daya dukung efektif KHGMU dengan memperhitungkan aspek pengelolaan. Dalam hal ini RCC dikalikan dengan faktor koreksi pengelolaan (MC). Berdasarkan wawancara dengan pengelola kawasan Hutan Gunung Mareje diketahui bahwa jumlah staf di resort pengelolaan KHGMU yang dapat memandu kegiatan wisata alam ke lokasi ODTWA seluruhnya berjumlah 6 orang, namun yang efektif bekerja setiap hari ke lapangan berjumlah 3 orang sehingga $M C=0,5$. Dengan demikian nilai kapasitas pelayanan pengelolaan di KHGMU hanya mampu melayani 50\% dari RCC atau sebesar 32.729 wisatawan/hari (Tabel 9).

Berdasarkan hasil wawancara dengan pengelola kawasan KHGMU keterbatasan pengembangan ekowisata disebabkan karena luasnya wilayah pengelolaan hutan Mareje-Bongak dengan tingkat ancaman terhadap kerusakan hutan yang tinggi. Staf lapangan mayoritas dialokasikan untuk kegiatan patroli pencegahan kerusakan hutan. Nilai ECC masih bisa ditingkatkan dengan mengoptimalkan kualitas manajemen pengelolaan, yaitu dengan meningkatkan jumlah staf pemandu lapangan sehingga meningkatkan ECC mencapai 100\% dari nilai RCC. Peningkatan layanan pemanduan kepada wisatawan akan mampu meningkatkan nilai ECC sekaligus meningkatkan kunjungan wisatawan (Lucyanti et al 2013)).

Hasil pengujian statistika menggunakan analisis paired t-test menunjukkan bahwa jumlah kunjungan wisatawan aktual berdasarkan data rata-rata kunjungan harian wisatawan selama dua tahun terakhir (2018-2019) masih lebih kecil dibandingkan daya dukung efektif kawasan. Hasil uji bersifat signifikan pada tingkat kepercayaan $95 \%(\mathrm{t}=-3,852$ dan $p$-value $=0,031)$. Rata-rata kunjungan wisatawan aktual di empat lokasi ODTWA sebesar 8 wisatawan/hari lebih kecil dibandingkan rata-rata ECC di empat lokasi tersebut sebesar 1.493 wisatawan/hari. Hasil uji ini menjelaskan bahwa jumlah kunjungan wisatawan ke lokasi ODTWA KHGMU yang ada saat ini tidak melebihi daya dukung kawasan (Tabel 9 dan Gambar 9).

Berdasarkan wawancara dengan wisatawan dijelaskan bahwa minimnya kunjungan wisatawan ke KHGMU disebabkan karena wisatawan yang datang 
ke ODTWA di KHGMU didominasi oleh wisatawan lokal dari Kabupaten Lombok Tengah untuk keperluan wisata spiritual (ziarah makam) dan bertapa. Aktivitas minat khusus lainnya dari wisatawan adalah memancing yang hanya dilakukan oleh penduduk di sekitar KHGMU pada musim kemarau. Ketika musim kemarau tiba, masyarakat di sekitar KHGMU datang ke Embung atau Bendungan yang ada di sekitarnya untuk memancing ikan dan mengisi waktu luang, karena lahan sawah yang mereka miliki kering dan tidak bisa ditanami. Ketika musim penghujan tiba, mereka kembali beraktivitas mengelola lahan pertanianya.

Tabel 9. Hasil perhitungan ECC dan Evaluasi Lahan di KHGMU

\begin{tabular}{lcccc}
\hline \multicolumn{1}{c}{ ODTWA } & $\begin{array}{c}\text { Actual } \\
\text { Kujungan } \\
\text { (wisatawan } \\
\text { /hari) }\end{array}$ & $\begin{array}{c}\text { RCC } \\
\text { (wisatawan } \\
\text { /hari) }\end{array}$ & MC & $\begin{array}{c}\text { ECC } \\
\text { (wisatawan } \\
\text { /hari) }\end{array}$ \\
\hline Embung Mapasan & $3^{\mathrm{a}}$ & 4.378 & 0,5 & $2.189^{\mathrm{b}}$ \\
Bukit Pupuh & $22^{\mathrm{a}}$ & 1.227 & 0,5 & $613^{\mathrm{b}}$ \\
Air Terjun Penangis Simbur & $4^{\mathrm{a}}$ & 4.147 & 0,5 & $2.074^{\mathrm{b}}$ \\
Makam Dewa Tongol & $2^{\mathrm{a}}$ & 2.194 & 0,5 & $1.097^{\mathrm{b}}$ \\
Seluruh Kawasan Gunung Mareje & 31 & 65.457 & 0,5 & 32.729 \\
Nilai t dari t-test perbandingan Actual kujungan wisatawan (a) dengan ECC (b) & $-3,852$ \\
\end{tabular}

* Signifikan pada tingkat kepercayaan $95 \%$

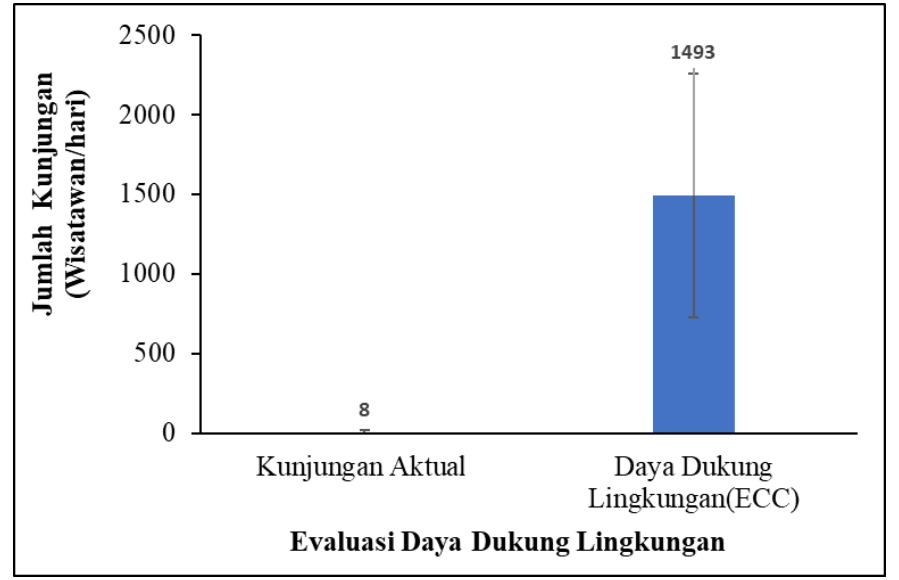

Gambar 9. Grafik evaluasi daya dukung lingkungan

\section{SIMPULAN}

Berdasarkan hasil analisis kesesuaian lahan diketahui bahwa pengelolaan ekowisata di KHGMU yang saat ini berjalan telah memenuhi aspek-aspek kesesuaian lahan dan daya dukung lingkungan kawasan hutan sebagai penyedia jasa ekosistem untuk pengembangan ekowisata. Hal ini ditandai dengan pemanfaatan lahan aktual yang digunakan untuk mendukung kegiatan ekowisata berada pada kelas lahan yang sesuai dengan intensitas pemanfaatan lahan lebih kecil dibandingkan potensi lahan yang ada.

Faktor kunci kesesuaian lahan di KHGMU meliputi tanah, keanekaragaman jenis pohon, visibilitas dan daya tarik wisata. Hasil analisis daya dukung menunjukkan bahwa jumlah wisatawan aktual yang telah berkunjung ke KHGMU saat ini tidak melebihi daya dukung lingkungan yang tersedia.

\section{UCAPAN TERIMA KASIH}

Penulis mengucapkan terima kasih atas bantuan berbagai pihak yang telah memberikan dukungan terhadap penelitian ini, khususnya kepada Pemprov NTB, Pemkab Lombok Tengah, BMKG NTB, Balittanah Bogor serta seluruh pihak-pihak terkait yang telah memberikan izin penelitian dan akses terhadap data-data yang dibutuhkan dalam penelitian ini. Semoga penelitian ini dapat berguna sebagai salah satu input dalam penyusunan rencana pengelolaan ekowisata terpadu (RPET) di KHGMU dan di tempat lainnya. RPET seharusnya disusun dengan mempertimbangkan kesesuaian antara jenis aktivitas ekowisata yang dibutuhkan wisatawan dengan kemampuan dan daya dukung lahan yang ada. Penulis menyadari bahwa penelitian ini dapat disempurnakan dengan penggunaan K\&I kesesuaian lahan untuk pengembangan jenis ekowisata tertentu yang lebih spesifik dan menambah ukuran unit pengamatan. 


\section{DAFTAR PUSTAKA}

Ashari, A. (2013). Kajian tingkat erodibilitas beberapa jenis tanah di Pegunungan Baturagung Desa Putat dan Nglanggeran Kecamatan Patuk Kabupaten Gunungkidul. Informasi, Volume 1(39), 15-31. DOI: https://doi.org/10.21831/informasi.v0i2.4441

Bali, A., Seyed, M.M, Borhan, R., Nematollah, K, \& Mir M.K.Z (2015). A spatial decision support system for ecotourism development in Caspian Hyrcanian mixed forests ecoregion. Bol. Ciênc. Geod., sec. Artigos, Volume 1 (2), 340-353. DOI: https://doi.org/10.1590/S198221702015000200001

BPS Lombok Tengah. (2017). Kabupaten Lombok Tengah dalam Angka Tahun 2016. Kantor BPS Lombok Tengah. Praya.

Bunruamkaew, K. \& Murayama. (2011). Site suitability evaluation for ecotourism using GIS and AHP: A Case study of Surat Thani Province, Thailand..Procedia Social and Behavioral Sciences, Volume 21, 269278.DOI: https://doi.org/10.1016/j.sbspro.2011.07.024

Dishutbun Lombok Tengah. (2017). Statistik Kehutanan Lombok Tengah 2016. Kantor Dishutbun Lombok Tengah. Praya.

Fandeli, C. \& Muhammad (2009). Prinsip - Prinsip Dasar Mengkonservasi Landskap. Universitas Gadjah Mada Press. Yogyakarta.

Friedman, H.J. (2002). Stochastic gradient boosting. computational statistics \& data analysis, Volume 38(4), 367-378. DOI: https://doi.org/10.1016/S0167-9473(01)00065-2.

Hardjowigeno, S., \& Widiatmaka. (2018). Evaluasi Kesesuaian Lahan dan Perencanaan Tata Guna Lahan. Gadjah Mada University Press. Yogyakarta

Ilmi, M.K. (2019). Kajian pengaruh perubahan tata guna lahan terhadap kondisi hidrologi daerah aliran sungai (DAS) Dodokan, Provinsi Nusa Tenggara Barat. Prosiding Konferensi Nasional Pascasarjana Teknik Sipil (KNPTS) X, ISSN 2477-00-86, 103113.

Arifin S., \& Utomo, B. (2018). Kajian pengembangan ekowisata Salang Pangeran Di Kawasan Taman Nasional Gunung Leuser. Serambi Engineering, Volume 3(1), 197-208. DOI: https://doi.org/10.32672/jse.v3i1.345
Kastarlak, B.I., \& Barber, B. (2014). Fundamentals of Planning and Developing Tourism. Pearson Education Limited. Essex, UK.

Lopez, J.M.R., Heiderb, K., \& Scheffran, J. (2017). Frontiers of urbanization: identifying and explaining urbanization hotspots in the south of Mexico City using human and remote sensing. Applied Geography, Volume 79, 1-10. DOI: https://doi.org/10.1016/j.dib.2016.12.049

Lucianti S., Boedi H., \& Munifatul, I. (2013). Penilaian daya dukung wisata di obyek wisata Bumi Perkemahan Palutungan Taman Nasional Gunung Ciremai Propinsi Jawa Barat. Prosiding seminar nasional pengelolaan sumberdaya alam dan lingkungan, ISBN 978-602-17001-1-2, 232-240.

Mirsanjari, M.M. (2012). Importance of environmental ecotourism planning for sustainable development. OIDA International journal of sustainable development, 4(2), 85-92.

Sandhyavitri, A., \& Ichsan, R. (2014). pengembangan kriteria-kriteria rencana pemindahan perkantoran di Kota Pekanbaru berdasarkan AHP (analytical hierarchy process). Jurnal Eko Rekayasa, Volume 10(1), 1-14.

Sugiyono. 2012. Metode Penelitian Kuantitatif Kualitatif dan R\&D. Alfabeta. Bandung.

Wickramasinghe, K. (2013). Ecotourism as a tool for sustainable forest management in Sri Lanka. Institute of Policy Studies of Sri Lanka (IPS), Volume $100(20), \quad 16-29 . \quad$ DOI: https://doi.org/10.4038/jepsl.v1i2.5145

Wiryanto, Sunarto, \& Slamet, M.R. (2017). biodiversity of mangrove aquatic fauna in Purworejo, Central Java, Indonesia. Biodiversitas, Volume 18(4), 1344-1352.

Zacarias, D.A., Wiliams, A.T., \& Newton, A. (2011). Recreation carrying capacity estimation to support beach management Praira de Faro Portugal. Jurnal of Applied Geography, Volume 31, 10751081.DOI:https://doi.org/10.1016/j.apgeog.2011. 01.020 